\title{
PENGARUH UPAH MINIMUM, PDRB, DAN TINGKAT INFLASI TERHADAP KESEJAHTERAAN MASYARAKAT KABUPATEN NUNUKAN
}

\author{
THE EFFECT OF MINIMUM WAGES, GRDP, AND INFLATION \\ LEVELS ON COMMUNITY WELL-BEING IN NUNUKAN DISTRICT
}

\author{
Charitin Devi \\ Program Studi Ekonomi Pembangunan, Universitas Borneo Tarakan \\ Charitin.devi@gmail.com
}

\begin{abstract}
Abstrak: Latar belakang masalah dalam penelitian ini adalah permasalahan pada tingkat kesejahteraan masyarakat Kabupaten Nunukan yang ditunjukkan dengan capaian Indeks Pembangunan Manusia (IPM) terendah diantara Kabupaten/Kota di Provinsi Kalimantan Utara. Tingkat kesejahteraan masyarakat Kabupaten Nunukan tersebut tidak sejalan dengan kenaikan upah minimum kabupaten, nilai PDRB Kabupaten Nunukan yang berada pada dua tertinggi di Provinsi Kalimantan Utara, serta kondisi tingkat inflasi yang rendah. Hasil dari analisa regresi berganda yang dilakukan untuk periode 2005-2019 dengan menggunakan software eviews adalah bahwa Kesejahteraan Masyarakat Kabupaten Nunukan secara parsial dipengaruhi parsial oleh PDRB (Product Domestic Regional Bruto) Kabupaten Nunukan secara signifikan dengan kontribusi sebesar 0,000000000000843, sedangkan Upah Minimum Regional Kabupaten Nunukan dan Inflasi Kota Tarakan dan Kota Balikpapan tidak signifikan berpengaruh. Namun secara simultan ketiga variabel bebas bepengaruh siginifikan dan dapat menjelaskan sebesar 54,2\% terhadap Kesejahteraan Masyarakat Kabupaten Nunukan.
\end{abstract}

Kata kunci: Upah, PDRB, Inflasi, Kesejahteraan, IPM

Abstract: The background of the problem in this study is the problem at the level of community welfare in Nunukan Regency which is shown by the lowest Human Development Index (HDI) achievement among regencies / cities in North Kalimantan Province. The level of welfare of the people of Nunukan Regency is not in line with the increase in the district's minimum wage, the PDRB value of Nunukan Regency which is the two highest in North Kalimantan Province, and conditions of low inflation rates. The results of the multiple regression analysis carried out for the period 2005-2019 using the eviews software are that the Welfare of the People of Nunukan Regency is partially affected by the PDRB (Gross Regional Domestic Product) of Nunukan Regency significantly with a contribution of -0.00000000000000843, while the Regional Minimum Wage 
Nunukan District and the City of Tarakan Inflation and Balikpapan City have no significant effect. But simultaneously the three independent variables have a significant effect and can explain $54.2 \%$ of the Community Welfare in Nunukan Regency.

Keywords: Wages, GRDP, Inflation, Welfare, HDI

\section{PENDAHULUAN}

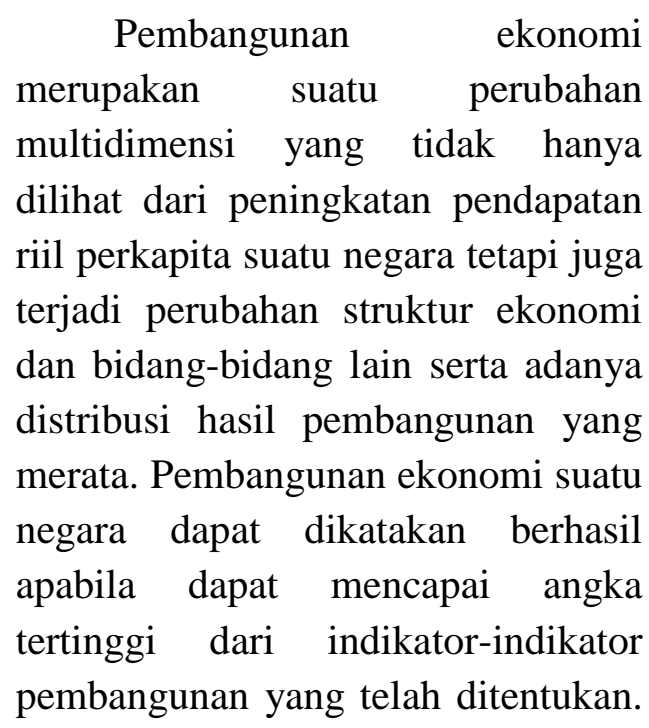
Tingkat kesejahteraan masyarakat merupakan salah satu indikator sosial dalam menilai keberhasilan pembangunan ekonomi.

Dalam lima tahun terakhir, indeks pembangunan manusia di Indonesia mengalami peningkatan. Hingga tahun 2019 capaian indeks pembangunan manusia adalah sebesar 71.92 (BPS, 2020). Dalam data statistik, Kabupaten Nunukan sebagai bagian dari Provinsi Kalimantan Utara menempati urutan terendah dalam capaian Indeks Pembangunan Manusia dalam dua tahun terakhir yaitu tahun 2018 sebesar 65,67 dan tahun 2019 sebesar 66,32 dibandingkan dengan empat kabupaten/kota lainnya di Provinsi Kalimantan Utara (ditunjukkan dalam tabel 1.). Dalam hal ini berbeda dengan nilai PDRB yang menempati dua terbesar di Kalimantan Utara setelah Kota Tarakan yaitu Rp.14.861.056,30 (dalam juta) tahun 2018 dan Rp. 15.866.409,90 (dalam juta) (BPS, 2020).

Sedangkan dalam data statistik ketenagakerjaan, sesuai dengan Surat Keputusan (SK) Gubernur Kalimantan Utara (Kaltara) No. 188.44/K.735/2018, upah minimum Kabupaten Nunukan Tahun 2019 ditetapkan Rp. 2.841.3381, besaran ini meningkat sebesar $8,02 \%$ dari tahun 2018 yaitu Rp. 2.630.178. Dengan meningkatnya upah minimum diharapkan kesejahteraan masyarakat Kabupaten Nunukan juga ikut meningkat dengan nilai Indeks Pembangunan Manusia yang tinggi, namun ternyata sebaliknya. 
Tabel 1.

Indeks Pembangunan Manusia Kabupaten Nunukan (2017-2019)

\begin{tabular}{|l|r|r|r|}
\hline \multicolumn{1}{|c|}{ Kabupaten/Kota } & \multicolumn{1}{c|}{$\mathbf{2 0 1 7}$} & $\mathbf{2 0 1 8}$ & \multicolumn{1}{c|}{$\mathbf{2 0 1 9}$} \\
\hline Malinau & 71.23 & 71.74 & 72.06 \\
\hline Bulungan & 70.74 & 71.23 & 71.66 \\
\hline Tana Tidung & 66.26 & 67.05 & 67.79 \\
\hline Nunukan & 65.1 & 65.67 & 66.32 \\
\hline Tarakan & 75.27 & 75.69 & 76.09 \\
\hline
\end{tabular}

Sumber : BPS, 2020

Tingkat inflasi sebagai indikator dari perekonomian turut berperan terhadap tingkat kesejahteraan masyarakat. Tingkat inflasi yang tinggi dapat mengakibatkan daya beli masyarakat melemah dan dapat menurunkan tingkat kesejahteraan masyarakat. Selama 5 tahun terakhir (2015 2019) tingkat Inflasi tertinggi Kota Tarakan adalah sebesar 5\% di tahun 2018, dan angka tesebut menurun tahun 2019 menjadi 1,47\% diikuti dengan meningkatnya daya beli masyarakat sebesar 4,58\% (BPS, 2020). Namun peningkatan daya beli ini merupakan yang terendah diantara kabupaten /kota di Provinsi Kalimantan Utara.

Secara keseluruhan kinerja dari statisik perekonomian dan tenaga kerja Kabupaten Nunukan ini belum dapat menjamin kelangsungan dari kualitas hidup masyarakatnya jika tingkat kesejahteraan masyarakatnya pun masih dalam kategori tingkat rendah. Uraian di atas menjadi alasan untuk dilakukan suatu penelitian dengan tujuan untuk mengetahui pengaruh upah minimum, PDRB, tingkat inflasi terhadap kesejahteraan masyarakat Kabupaten Nunukan Tahun 20052019.

\section{Rumusan Masalah}

Rumusan masalah penelitian ini adalah: Apakah terdapat hubungan antara upah minimum, PDRB, tingkat inflasi secara parsial maupun simultan terhadap kesejahteraan Kabupaten Nunukan Kalimantan Utara?

\section{Tujuan Penelitian}

Tujuan dari penelitian ini adalah untuk mengetahui pengaruh upah minimum, PDRB, tingkat inflasi baik secara parsial maupun simultan terhadap kesejahteraan masyarakat Kabupaten Nunukan Kalimantan Utara Tahun 2005 2019.

\section{TINJAUAN PUSTAKA \\ Upah}

Pengertian mengenai upah menurut Undang Undang Nomor 13 Tahun 2003 tentang ketenagakerjaan pasal 1 yaitu hak pekerja yang diterima dan dinyatakan dalam bentuk uang sebagai imbalan dari pengusaha atau pemberi kerja kepada 
pekerja yang ditetapkan dan dibayarkan menurut suatu perjanjian kerja, kesepakatan, atau peraturan perundang undangan, termasuk tunjangan bagi pekerja dan keluarganya atas suatu pekerjaan dan/atau jasa yang telah atau akan dilakukan.

Beberapa faktor yang dapat mempengaruhi peningkatan upah tenaga kerja diantaranya adalah sebagai berikut:

a. Jam kerja

b. Lama Kerja

c. Tingkat Pendidikan

Beberapa ketentuan yang berkaitan dengan upah di Indonesia, antara lain:

1. Undang-undang Nomor 13 Tahun $2003 \quad$ Tentang Ketenagakerjaan Pasal 88-97

2. Peraturan Pemerintah Nomor 78 Tahun 2015 Tentang Pengupahan

3. Peraturan Menteri

Ketenagakerjaan Nomor 1 Tahun 2017 Tentang Struktur dan Skala Upah.

\section{PDRB (Product Domestic Regional Bruto)}

PDRB (Produc Domestic Regional Bruto) adalah total nilai tambah (value added) yang dihasilkan oleh seluruh unit usaha atau merupakan total nilai barang dan jasa yang dihasilkan oleh seluruh unit ekonomi di suatu wilayah. PDRB merupakan salah satu indikator kinerja perekonomian daerah.

Cara menghitung PDRB dilakukan melalui tiga pendekatan yaitu Produksi, Pengeluaran dan Pendapatan.

\section{Inflasi}

Inflasi diartikan sebagai suatu proses meningkatnya harga-harga secara umum dan terus-menerus (continue) berkaitan dengan mekanisme pasar yang dapat disebabkan oleh berbagai factor.

Berdasarkan sumber atau penyebab kenaikan harga - harga yang berlaku, inflasi dibedakan dalam dua spesifikasi yaitu sebagai berikut (Sukirno, 1994).

1. Inflasi dilihat dari penyebabnya

a. Demand-Pull Inflation

Demand-pull Inflation disebabkan oleh permintaan masyarakat akan barang barang (agregate demand) bertambah.

b. Cost Push Inflation

Inflasi jenis Cost - Push Inflation terjadi karena kenaikan biaya produksi, yang disebabkan oleh terdepresiasinya nilai tukar, dampak inflasi luar negeri terutama negara- negara partner dagang, peningkatan harga - harga komoditi yang diatur pemerintah (administered price), dan terjadi negative supply shocks akibat bencana alam dan tergangggunya distribusi.

2. Inflasi ditinjau dari asal inflasi

a. Inflasi dari dalam negeri (domestic inflation)

Inflasi ini timbul misalnya karena kenaikan gaji pegawai negeri, panenan gagal dan sebagainya.

b. Inflasi dari luar negeri (imported inflation) 
Inflasi ini timbul karena kenaikan harga - harga di luar negeri atau di negara negara mitra dagang. Inflasi juga dapat bersumber dari barang - barang yang diimpor.

\section{Kesejahteraan Masyarakat}

Kesejahteraan menurut Brudeseth (2015) adalah kualitas kepuasan hidup yang bertujuan untuk mengukur posisi anggota masyarakat dalam membangun keseimbangan hidup mencakup yaitu kesejahteraan materi, kesejahteraan bermasyarakat, kesejahteraan emosi, dan keamanan.

Menurut Undang-undang No. 11 Tahun 2009, tentang Kesejahteraan Masyarakat, kesejahteraan masyarakat adalah kondisi terpenuhinya kebutuhan material, spiritual, dan sosial warga negara agar dapat hidup layak dan mampu mengembangkan diri, sehingga dapat melaksanakan fungsi sosialnya.

Indeks Pembangunan Manusia merupakan salah satu indikator untuk menentukan tingkat kesejahteraan masyarakat. Di Indonesia Indeks Pembangunan Manusia dihitung oleh Badan Pusat Statistik (BPS) dengan menggunakan beberapa komponen yaitu:

a. Umur panjang dan hidup sehat diukur dengan angka harapan hidup pada waktu lahir (life expectancy at birth);

b. Pengetahuan diukur dengan angka melek huruf (literacy rate) dan rata-rata lama sekolah (mean years of schooling),

c. Standar Hidup Layak diukur dengan kemampuan daya beli (purchasing power parity)

Setiap komponen IPM distandardisasi dengan nilai minimum dan maksimum sebelum digunakan untuk menghitung IPM. Rumus yang digunakan sebagai berikut.

1. Kesehatan

$$
\begin{aligned}
& I_{\text {Kesehatan }} \\
& =\frac{A H H-A H H_{\text {Min }}}{A H H_{\text {Maks }}-A H H_{\text {Min }}}
\end{aligned}
$$

2. Pendidikan terdiri dari dua komponen rata-rata lama sekolah (RLS) dan harapan lama sekolah (HLS)

$$
\begin{gathered}
I R L S=\frac{R L S-R L S_{\text {Min }}}{R L S_{\text {Maks }}-R L S_{\text {Min }}} \\
I H L S=\frac{H L S-H L S_{\text {Min }}}{H L S_{\text {Maks }}-H L S_{\text {Min }}}
\end{gathered}
$$

Indeks dari kedua komponen tersebut diberi bobot yang sama dalam menyusun indeks pendidikan.

$$
I_{\text {Pendidikan }}=\frac{I R L S+I H L S}{2}
$$

\section{Pengeluaran}

$$
\begin{aligned}
& I_{\text {Pengeluaraan }} \\
& =\frac{\operatorname{In}(P P P)-\operatorname{Ln}\left(P P P_{\text {Min }}\right)}{\operatorname{Ln}\left(P P P_{\text {Maks }}\right)-\operatorname{Ln}\left(P P P_{\text {Min }}\right)}
\end{aligned}
$$

Selanjutnya IPM dihitung dengan rumus rata-rata geometrik $I P M$

$=\sqrt[3]{I_{\text {Kesehatan }} \mathrm{X} I_{\text {Pendidikan }} \mathrm{X} I_{\text {Pengeluaran }}}$ 
Nilai IPM dikelompokkan menjadi 4 kelompok untuk melihat capaian pembangunan manusia di suatu wilayah. Kelompok nilai IPM tersebut adalah

1. Kelompok "sangat tinggi": IPM $\geq 80$

2. Kelompok "tinggi": $70 \leq$ IPM $<80$

3. Kelompok "sedang": $60 \leq$ IPM $<70$

4. Kelompok "rendah": IPM < 60

Semakin tinggi nilai Pertumbuhan IPM di suatu wilayah artinya semakin cepat pembangunan manusia di wilayah tersebut.

\section{METODOLOGI PENELITIAN}

\section{Desain Penelitian}

Jenis penelitian ini adalah penelitian kuantitatif, dimana pada penelitian kuantitatif penyajian data didominasi dalam bentuk angka dan analisis data yang digunakan bersifat statistik dengan tujuan untuk menguji hipotesis. Penelitian ini juga bersifat deskriptif verifikatif untuk memberikan gambaran mengenai hubungan upah minimum, PDRB, tingkat inflasi terhadap kesejahteraan masyarakat Kabupaten Nunukan tahun 2005 - 2019 serta menguji hipotesis dan teori yang sudah ada.

\section{Jenis Dan Sumber Data}

Penelitian ini menggunakan data sekunder yaitu data yang diperoleh dari Badan Pusat Statistik Kabupaten Nunukan, Kota Tarakan, dan Provinsi Kalimantan Utara. Data yang digunakan meliputi Upah Minimum, PDRB, Tingkat Inflasi dan Indeks Pembangunan Manusia. Data lain yang mendukung penelitian ini diambil dari berbagai sumber lain yang berhubungan baik secara langsung maupun tidak langsung dengan permasalahan penelitian untuk menjadi sumber, pedoman, atau petunjuk dalam penyelesaian masalah penelitian.

\section{Variabel Penelitian}

Variabel adalah objek penelitian atau merupakan suatu konsep yang memiliki nilai yang bermacam-macam. Dalam penelitian ini terdapat dua jenis variabel yang digunakan

a. Variabel Independen

Variabel independen adalah variabel yang mempengaruhi atau yang menjadi sebab perubahannya atau timbulnya variabel dependen (terikat) (Sugiyono, 2014). Variabel independen yang digunakan dalam penelitian ini adalah

1. Upah Minimum $\left(\mathrm{X}_{1}\right)$ Kabupaten Nunukan Tahun 2005 - 2019,

2. Product Domestic Regional Bruto (PDRB) $\quad\left(\mathrm{X}_{2}\right)$ Kabupaten Nunukan Tahun $2005-2019$

3. Tingkat Inflasi $\left(X_{3}\right)$ Kota Tarakan Tahun 2005 - 2019

b. Variabel dependen adalah variabel yang dipengaruhi atau yang menjadi akibat karena adanya variabel bebas (Sugiyono, 2014). Variabel 
dependen yang digunakan dalam penelitian ini adalah Kesejahteraan Masyarakat (Y) Kabupaten Nunukan Tahun 2005 - 2019.

\section{Metode Analisis Data}

\section{Pengujian Asumsi Klasik}

Sebelum data dianalisis dengan menggunakan analisis regresi maka dilakukan uji asumsi terhadap model dalam penelitian ini yang meliputi:

a. Uji Multikolinieritas.

Pengujian terhadap gejala multikolinearitas dalam penelitian ini dilakukan dengan menghitung Variance Inflation Factor (VIF) dari hasil estimasi.

- Ho : VIF > 10, terdapat multikolinearitas antar variabel independen.

- Ha : VIF < 10, tidak ada multikolinearitas antar variabel independen.

b. Uji heteroskedastisitas

Dalam penelitian ini untuk mendeteksi adanya masalah heteroskedastisitas dengan menggunakan uji Glejser. Uji Glejser dilakukan dengan cara meregresikan antara variabel independen dengan nilai absolut residualnya (ABS_RES).

- Jika nilai signifikansi (Sig.) antara variabel independen dengan absolut residual kurang dari 0,05 maka terjadi masalah heteroskedastisitas dalam model regresi

- Jika nilai signifikansi (Sig.) antara variabel independen dengan absolut residual lebih dari 0,05 maka tidak terjadi masalah heteroskedastisitas dalam model regresi

c. Uji autokorelasi.

Dalam mendeteksi masalah autokorelasi dalam penelitian ini digunakan BreuschGodfrey LM Test. Cara menentukan atau kriteria pengujian autokorelasi adalah membadingkan nilai signifikansi (Sig.) dari Breusch-Godfrey LM Test dengan probabilitas 5\%:

- Jika nilai signifikansi (Sig.) kurang dari 0,05 maka terjadi masalah autokorelasi dalam model regresi

- Jika nilai signifikansi (Sig.) lebih dari 0,05 maka tidak terjadi masalah autokorelasi dalam model regresi

\section{Analisis Regresi Berganda}

Data yang terkumpul akan dianalisis dengan analisis regresi linear berganda. Selanjutnya model estimasi untuk regresi tersebut adalah:

Persamaan Kesejahteraan Masyarakat Kabupaten Nunukan Bentuk Linier: 


$$
Y=\gamma_{0} X_{1}^{\gamma_{1}} X_{2}^{\gamma_{2}} X_{3}^{\gamma_{3}} \cdot e
$$

Bentuk Log Linier:

$$
\begin{gathered}
\operatorname{Ln} Y=\gamma_{0}+\gamma_{1} \operatorname{Ln} X_{1}+\gamma_{2} \operatorname{Ln} X_{2} \\
+\gamma_{3} \operatorname{Ln} X_{3}+. e
\end{gathered}
$$

Dengan :

\section{$Y$ : Kesejahteraan Masyarakat}

Kabupaten Nunukan

$\gamma_{0}:$ Intersep/Konstanta

$X_{1}$ : Upah Minimum Kabupaten

Nunukan (Rp./bulan)

$X_{2}: P D R B$ Kabupaten Nunukan (Rp.)

$X_{3}$ : Tingkat Inflasi Kota Tarakan

dan Kota Balikpapan (\%)

$\gamma_{1} ; \gamma_{2} ; \gamma_{3}$ : Koefisien Regresi

Sebelum dilakukan analisis regresi terlebih dahulu ditentukan model regresi yang lebih baik digunakan antara regresi linier atau $\log$ linier. Cara menentukan model regresi yang akan dipakai menggunakan metode MWD (Mackinnon, White dan Davidson). Setelah model regresi dipilih selanjutnya dilakukan beberapa pengujian pada model regresi tersebut antara lain:

a. Pengujian $\mathrm{T}-$ Statistik (Uji Parsial)

b. Pengujian F - Statistik (Uji Menyeluruh/Simultan)

c. Analisa Perhitungan Determinasi $\left(\mathrm{R}^{2}\right)$

HASIL DAN PEMBAHASAN

\section{Hasil Pengujian Asumsi Klasik}

Dalam analisa data penelitian ini dilakukan uji asumsi klasik. Hal ini dilakukan untuk menilai apakah di dalam sebuah model regresi OLS (Ordinary Least Square) terdapat masalah-masalah asumsi klasik. Beberapa uji asumsi klasik yang dilakukan dalam penelitian ini adalah uji multikolinearitas, uji heteroskedastisitas dan uji autokorelasi.

\section{Uji Multikolinieritas}

Untuk pengujian masalah multikolinieritas dilakukan dengan menghitung Variance Inflation Factor (VIF) dari hasil estimasi.

- Ho : VIF > 10, terdapat multikolinearitas antar variabel independen.

- Ha : VIF < 10, tidak ada multikolinearitas antar variabel independen.

Dalam penelitian ini nilai Variance Inflation Factor (VIF) didapatkan dengan menggunakan software eviews yang ditunjukkan pada tabel 2. Berdasarkan nilai Variance Inflation Factor (VIF) yang didapatkan dalam tabel 2. untuk PDRB, Upah Minimum dan Inflasi masing-masing bernilai kurang dari $10(<10)$ yang berarti tidak terdapat masalah multikolinieritas pada model persamaan regresi. 
Tabel 2.

Nilai VIF (Variance Inflation Factor) dalam uji Mulitikolinieritas

\begin{tabular}{|cccc|}
\hline $\begin{array}{l}\text { Variance Inflation Factors } \\
\text { Sample: 2005 2019 } \\
\text { Included observations: } 15\end{array}$ & & \\
\hline \hline Variable & $\begin{array}{c}\text { Coefficient } \\
\text { Variance }\end{array}$ & $\begin{array}{c}\text { Uncentered } \\
\text { VIF }\end{array}$ & $\begin{array}{c}\text { Centered } \\
\text { VIF }\end{array}$ \\
\hline \hline C & 15.83725 & 17.04700 & NA \\
UPAH_MINIMUM & $6.51 \mathrm{E}-12$ & 20.67337 & 3.897394 \\
PDRB & $9.15 \mathrm{E}-26$ & 10.49118 & 3.497097 \\
INFLASI & 0.056355 & 5.184215 & 1.512575 \\
\hline \hline
\end{tabular}

\section{Uji Heteroskedastisitas}

Pengujian masalah heteroskedastisitas pada penelitian ini adalah dengan membandingkan nilai signifikan (Sig.) variabel independen dengan nilai signifikan absolut residual (ABS_RES). Nilai absolut residual didapatkan dengan Uji Glejser yang dilakukan dengan software eviews.

Hasil pengujian data dengan Uji Glejser melalui software eviews menunjukkan nilai signifikan dari ABS_RES (Prob. Chi-Square(3) pada Obs*R-Square) adalah 0,1680 atau lebih dari 5\% ( $>5 \%$ atau > 0.05) yang berarti bahwa dalam model persamaan juga tidak terdapat masalah Heteroskedastisitas.

\section{Uji Autokorelasi}

Pada uji masalah klasik autokorelasi dilakukan dengan menggunakan Dalam mendeteksi masalah autokorelasi dalam penelitian ini digunakan BreuschGodfrey LM Test. Nilai Signifikansi (Sig.) yang didapatkan dengan menggunakan software eviews adalah 0.3439 (Prob. Chi-Square pada Obs*R-Square). Nilai ini lebih besar dari probabilitas 5\% atau 0,05 yang berarti bahwa dalam model tidak terdapat masalah autokorelasi.

\section{Analisis Regresi Berganda}

Berdasarkan hasil aplikasi metode MWD (Mckinon, White and Davidson) dengan menggunakan software eviews dihasilkan bahwa model yang baik digunakan adalah model persamaan linear.

Model persamaan linear dalam penelitian ini adalah

$$
Y=\gamma_{0} X_{1}^{\gamma_{1}} X_{2}{ }^{\gamma_{2}} X_{3}{ }^{\gamma_{3}} \cdot e
$$

Dimana :

$Y$ : Kesejahteraan Masyarakat

Kabupaten Nunukan

$\gamma_{0}:$ Intersep/Konstanta

$X_{1}$ : Upah Minimum Kabupaten

Nunukan (Rp./bulan)

$X_{2}: P D R B$ Kabupaten Nunukan (Rp.)

$X_{3}$ : Tingkat Inflasi Kota

Tarakan dan Kota

Balikpapan(\%)

$\gamma_{1} ; \gamma_{2} ; \gamma_{3}$ : Koefisien Regresi 
Setelah ditentukan model persamaan dalam penelitian ini yaitu model persamaan linear dan dilakukan pengujian asumsi klasik yang menghasilkan bahwa dalam model tidak terdapat masalah multikolinieritas, masalah heteroskedastisitas dan masalah autokorelasi selanjutnya dilakukan analisis dari hasil regresi. Analisa regresi berganda dilakukan untuk mengetahui hubungan dari berbagai variabel yang terdapat dalam penelitian ini yaitu hubungan antara variabel Indeks Pembangunan Manusia (IPM)/Kesejahteraan Masyarakat Kabupaten Nunukan dengan variabel PDRB (Product Domestic Regional Bruto), Upah Minimum Regional di Kabupaten Nunukan dan variabel Inflasi selama rentang waktu 2005-2019.

Analisa regresi berganda pada penelitian dilakukan dengan menggunakan software eviews dan hasil regresi ditunjukkan pada tabel 3.

Tabel 3.

Hasil Regresi

Dependent Variable: IPM

Method: Least Squares

Sample: 20052019

Included observations: 15

\begin{tabular}{lrlrl}
\hline \hline \multicolumn{1}{c}{ Variable } & Coefficient & Std. Error & t-Statistic & Prob. \\
\hline \hline \multicolumn{1}{c}{ C } & 66.71434 & 3.979604 & 16.76406 & 0.0000 \\
UPAH_MINIMUM & $3.54 \mathrm{E}-06$ & $2.55 \mathrm{E}-06$ & 1.387902 & 0.1926 \\
\multicolumn{1}{c}{ PDRB } & $-8.43 \mathrm{E}-13$ & $3.03 \mathrm{E}-13$ & -2.787210 & 0.0177 \\
\multicolumn{1}{c}{ INFLASI } & 0.161083 & 0.237392 & 0.678553 & 0.5114 \\
\hline \hline R-squared & 0.542409 & Mean dependent var & 66.34200 \\
Adjusted R-squared & 0.417612 & S.D. dependent var & 4.891648 \\
S.E. of regression & 3.733030 & Akaike info criterion & 5.695496 \\
Sum squared resid & 153.2907 & Schwarz criterion & 5.884309 \\
Log likelihood & -38.71622 & Hannan-Quinn criter. & 5.693485 \\
F-statistic & 4.346314 & Durbin-Watson stat & 1.257305 \\
Prob(F-statistic) & 0.029947 & & \\
\hline \hline
\end{tabular}

Dari hasil regresi pada tabel 3. dapat dibentuk model persamaan linear dalam penelitian :

$Y=66,71434-0,000000000000843$ $X_{1}+0,00000354 X_{2}+0,161083 X_{3}$

Berdasarkan hasil tersebut dapat disimpulkan bahwa: a. Kesejahteraan Masyarakat Kabupaten Nunukan dipengaruhi oleh Upah Minimum Regional, PDRB (Product Domestic Regional Bruto), dan Inflasi dengan masing-masing kontribusi adalah 0,00000354 oleh variabel Upah Minimum Regional Kabupaten Nunukan; - 
0,000000000000843 oleh variabel PDRB Kabupaten Nunukan; dan 0,161083 oleh variabel inflasi di Kota Tarakan dan Kota Balikpapan

b. Kontribusi oleh konstanta adalah sebesar 66,71434 atau jika ketiga variabel independen berkontribusi sebesar 0 maka IPM (Kesejahteraan Masyarakat Kabupaten Nunukan) akan sebesar 66,71434.

c. Kontribusi variabel Upah Minimum Regional Kabupaten Nunukan adalah sebesar 0,00000354 atau jika variabel ini meningkat sebesar 1\% maka IPM (Kesejahteraan Masyarakat Kabupaten Nunukan) akan meningkat sebesar $0,00000354 \%$ d. Kontribusi variabel PDRB

Kabupaten Nunukan adalah sebesar $\quad-0,000000000000843$ atau jika PDRB meningkat sebesar $1 \%$ maka IPM (Kesejahteraan Masyarakat Kabupaten Nunukan) akan menurun sebesar 0,000000000000843\%

e. Kontribusi variabel Inflasi Kota Tarakan dan Kota Balikpapan adalah sebesar 0,161083 atau jika variabel ini meningkat sebesar 1\% maka IPM (Kesejahteraan Masyarakat Kabupaten Nunukan) akan meningkat sebesar $0,161083 \%$

\section{Pengujian Hipotesis}

\section{Uji T-Statistik}

Tabel 4.

Pengujian T-Statistik Dari Hasil Regresi

\begin{tabular}{|l|c|c|c|c|}
\hline \multicolumn{1}{|c|}{ Variabel } & Koefisien & T-Statistik & $\begin{array}{c}\text { Probabilitas } \\
(\boldsymbol{\rho} \text {-value })\end{array}$ & Keterangan \\
\hline Konstanta & - & 16.76406 & 0.0000 & - \\
\hline $\begin{array}{l}\text { Upah Minimum } \\
\text { Regional Kabupaten } \\
\text { Nunukan }\end{array}$ & 0,00000354 & 1.387902 & 0.1926 & $\begin{array}{c}\text { Tidak } \\
\text { Signifikan }\end{array}$ \\
\hline $\begin{array}{l}\text { PDRB Kabupaten } \\
\text { Nunukan }\end{array}$ & $-0,000000000000843$ & -2.787210 & 0.0177 & Signifikan \\
\hline $\begin{array}{l}\text { Inflasi Kota Tarakan } \\
\text { dan Kota Balikpapan }\end{array}$ & 0.161083 & 0.678553 & 0.5114 & $\begin{array}{c}\text { Tidak } \\
\text { Signifikan }\end{array}$ \\
\hline
\end{tabular}

Berdasarkan hasil regresi pada tabel 4. Diketahui secara parsial thitung untuk masing-masing variabel adalah $-2,787210$ untuk variabel PDRB Kabupaten Nunukan, 1,387902 untuk variabel Upah Minimum Regional Kabupaten
Nunukan dan 0,678553 untuk variabel Inflasi Kota Tarakan dan Kota Balikpapan. Dan untuk t-tabel pada penelitian ini dengan df (11) dan $\alpha=5 \%$ adalah 2,20099. Sehingga dapat disimpulkan bahwa dari ketiga variabel yang digunakan 
dalam penelitian hanya PDRB Kabupaten Nunukan siginifikan terhadap Kesejahteraan Masyarakat Kabupaten Nunukan sedangkan Upah Minimum Regional Kabupaten Nunukan dan Inflasi Kota Tarakan dan Kota Balikpapan berpengaruh tidak signifikan terhadap Kesejahteraan Masyarakat Kabupaten Nunukan.

Tidak signifikan pengaruh yang diberikan oleh variabel Upah Minimum Regional Kabupaten Nunukan berarti bahwa kenaikan dari variabel ini memberikan perubahan terhadap Kesejahteraan Masyarakat. Ini dikarenakan kenaikan dari Upah Minimum Regional hanya berpengaruh kepada Kesejahteraan Tenaga Kerja dan anggota keluarganya saja, sedangkan kelompok masyarakat bukan tenaga kerja tidak terpengaruh oleh variabel ini.

Tingkat Inflasi pada penelitian ini juga berpengaruh tidak signifikan terhadap perubahan Kesejahteraan Masyarakat. Dalam komponen Indeks Pembangunan Manusia yang mewakili Kesejahteraan Masyarakat Kabupaten Nunukan yaitu kesehatan, pendidikan dan daya beli masyarakat (pengeluaran) tidak terpengaruh oleh tingkat inflasi yang terjadi (dalam hal ini menggunakan tingkat Inflasi Kota Tarakan dan Kota Balikpapan). Hal ini dapat dilihat dari data Inflasi menurut kelompok pengeluaran dari data BPS Inflasi untuk kelompok pendidikan dan kesehatan memberikan nilai yang kecil diantara kelompok pengeluaran lainnya. Dan saat ini banyak bantuan yang diberikan oleh pemerintah dalam bidang pendidikan dan kesehatan, untuk itu Inflasi yang disumbang oleh pendidikan dan pengeluaran tidak berpengaruh terhadap Kesejahteraan Masyarakat khususnya di Kabupaten Nunukan selama rentang waktu 2005 sampai dengan 2019.

\section{Pengujian F-Statistik}

Kesimpulan terhadap pengujian F-Statistik dapat dilihat dengan membandingkan nilai Fhitung pada tabel 5. yaitu 4,346314 dengan F-tabel dengan df $(3,11)$ yaitu 3,587. Dari perbandingan F-hitung dengan F-tabel dapat dihasilkan kesimpulan bahwa ketiga variabel dalam penelitian secara simultan berpengaruh signifikan terhadap Kesejahteraan Masyarakat Kabupaten Nunukan, meskipun secara parsial hanya PDRB Kabupaten Nunukan yang berpengaruh signifikan.

\section{Analisa Perhitungan \\ Determinasi $\left(\mathbf{R}^{\mathbf{2}}\right)$}

Nilai determinasi $\left(\mathrm{R}^{2}\right)$ pada penelitian biasanya menunjukkan seberapa besar kemampuan variabelvariabel bebas yang ada di dalam suatu penelitian dalam menjelaskan variabel terikatnya. Perhitungan nilai determinasi dalam penelitian ini didapatkan dengan menggunakan software eviews dalam hasil regresi yang ditunjukkan pada tabel 5 .

Pada tabel 3. nilai $\mathrm{R}^{2}$ adalah sebesar 0.542409 atau variabelvariabel bebas dalam penelitian ini 
dapat menjelaskan Kesejahteraan Masyarakat Kabupaten Nunukan sebesar 54,2\% sedangkan sisanya dijelaskan oleh variabel lain yang tidak digunakan sebagai parametrik dalam penelitian ini.

\section{SIMPULAN DAN SARAN}

\section{Simpulan}

Berdasarkan hasil regresi menunjukkan bahwa Kesejahteraan Masyarakat Kabupaten Nunukan dipengaruhi oleh PDRB (Product Domestic Regional Bruto) dengan kontribusi $\quad-0,000000000000843$ sedangkan Upah Minimum Regional Kabupaten Nunukan dan Inflasi Kota Tarakan dan Kota Balikpapan berpengaruh tidak signifikan terhadap Kesejahteraan Masyarakat Kabupaten Nunukan.

\section{Saran}

Saran atas hasil penelitian yang dilakukan adalah perlu untuk memperhatikan PDRB Kabupaten Nunukan yang memberikan kontribusi terhadap Kesejahteraan Masyarakat. Dalam penelitian ini kontribusi yang diberikan oleh PDRB Kabupaten Nunukan adalah bernilai negatif, sehingga jika terjadi peningkatan terhadap PDRB Kabupaten Nunukan maka akan diikuti penurunan Kesejahteraan Masyarakat Kabupaten Nunukan. Hal ini disebabkan hasil dari PDRB tidak terdistribusi secara merata kepada seluruh Masyarakat Kabupaten Nunukan. Pemerintah dalam hal ini Pemerintah Kabupaten Nunukan harus memperhatikan masalah pendistribusian dari hasil pendapatan regional tersebut agar tidak terjadi masalah ketimpangan pendapatan dan selanjutnya dapat memberikan efek positif terhadap Kesejahteraan Masyarakat Kabupaten Nunukan.

\section{DAFTAR PUSTAKA}

Badan Pusat Statistik (BPS). Diakses dari http://www.bps.go.id/, April dan Mei 2020.

Jayanthi, Ni Kadek Eka. 2019. Analisis Pengaruh Investasi, Ekspor, Inflasi Terhadap Pertumbuhan Ekonomi Dan Kesejahteraan Masyarakat di Provinsi Bali. E-Jurnal Ekonomi Pembangunan, Universitas Udayana.

Prasetyo, Hendrawan. 2019. Implementasi Dari Kebijakan Upah Minimum Kabupaten (UMK) Dan Pengaruhnya Terhadap Kesejahteraan Masyarakat (Studi Pada Kabupaten Kebumen). Fokus Bisnis : Media Pengkajian Manajemen Dan Akuntansi, Kebumen.

Sari, Catur Nanda Puspita, dkk. 2019. Analisis Pengaruh Inflasi dan Investasi Terhadap Pertumbuhan Ekonomi dan Kesejahteraan Masyarakat di Pulau Jawa Tahun 2006-2016. Jurnal Ekuilibrium, Universitas Jember.

Sinaga, Anton A.P. 2016. Analisis Faktor - Faktor yang Mempengaruhi

Kesejahteraan Masyarakat di 
Kota Medan (Studi Kasus

Usaha Kecil dan Menengah).

Jurnal Ilmiah Methonomi, Medan.

Sugiyono. 2014. Metode Penelitian

Pendidikan Pendekatan

Kuantitatif, Kualitatif, dan

$R \& D$. Bandung: Alfabeta

Sukirno, $\quad 2013$.

Makroekonomi: Teori

Pengantar. PT. Raja Grafindo

Persada. Jakarta.

Sulistiawati, Rini. 2012. Pengaruh Upah Minimum Terhadap Penyerapan Tenaga Kerja Dan Kesejahteraan Masyarakat Di Provinsi Di Indonesia. Jurnal Eksos, Pontianak.

Teneh, Endrico Geraldo, Anderson G. Kumenaung, Amran T. Naukoko. 2019. Dampak Upah Minimum Provinsi Terhadap Penyerapan Tenaga Kerja Dan Kesejahteraan Masyarakat Di Pulau Sulawesi. Jurnal Berkala Ilmiah Efisiensi, Manado.

Widarjono, 2013. Ekonometrika: Pengantar dan aplikasinya. Ekonisia, Yogyakarta.

Zainuddin. 2015. Analisis Dampak Inflasi, PDRB Dan Perkembangan Upah Minimum Regional Terhadap Indeks Pembangunan Manusia Masyarakat Di Provinsi Aceh. Jurnal Ekonomi Manajemen dan Akuntansi, Banda Aceh. 